Arch. Vet. Science 3(1):87-93, 1998

Printed in Brazil

\title{
SENSITIVITY OF THE ANTARCTIC FISH Notothenia neglecta EXPERIMENTALY INTOXICATED WITH THE NON POLUTANT ANTICHOLINESTERASE AGENT MALATHION [O, O-Dimethyl S- (1,2-dicarbethoxyethyl) phosphorodithioate]
}

\author{
NEUZA MARIA FERRAZ DE MELLO GONÇALVES ${ }^{1}$; WILMA P. BASTOS-RAMOS ${ }^{2}$; \\ METRY BACILA ${ }^{3}$
}

Brazilian Antarctic Station Commander Ferraz, Admiralty Bay, King George Island, South Shettlands.

${ }^{1}$ Departamento de Medicina, Divisão de Ciências Biológicas e da Saúde, Pontifícia Universidade Católica do

Paraná, Curitiba, Paraná, Brasil. ${ }^{2}$ Departamento de Ciências Básicas, Faculdade de Odontologia, Universidade Estadual Paulista (UNESP), S. José dos Campos, S. Paulo, Brasil. ${ }^{3}$ Laboratório de Piscicultura, Departamento de Zootecnia, Universidade Federal do Paraná.

\begin{abstract}
A research has been carried out on the sensitivity of the Antarctic fish Notothenia neglecta towards the non-pollutant anticholinesterase agent Malathion [O,O-dimethyl S-(1,2-dicarbethoxyethyl) phosphorodithioate]. Specimens of $N$. neglecta were injected with Malathion in doses of 15 or $30 \mathrm{mg} / \mathrm{kg}_{\mathrm{bw}}$ and observed regarding their behavior, somatic and physiological responses during ten days. They were monitored by the assay of serum cholinesterase activity as well as by the observation of respiratory depression and by the catatonic behavior, changes of body color and cholinergic muscarinic responses. Results of this experiment showed that $N$. neglecta is significantly more sensitive to Malathion as compared to the fresh water fish Oreochomis niloticus. At the end of the experiment all waste material was packed up and carried to our laboratories back home.
\end{abstract}

Key Words: Antarctic fish - Notothenia neglecta - Anticholinesterase drugs -Malathion.

RESUMO - Foi levada a efeito um estudo sobre a sensibilidade do peixe antártico Notothenia neglecta ao agente anticolinesterásico não poluente Malathion [O-O-dimetil S-(1,2-dicarbetoxietil) fosforoditioato]. Especimens de $N$. neglecta foram injetados com Malathion em doses de 15 ou $30 \mathrm{mg} / \mathrm{kg}$ de peso corpóreo e observados durante dez dias. O experimento foi monitorado pela determinação da atividade anticolinesterásica sérica bem como pela observação da depressão respiratória, pelo comportamento catatônico dos animais, pela mudança da coloração corpórea e pelas respostas colinérgicas muscarínicas. Os resultados desse experimento mostraram que a $N$. neglecta é significantemente mais sensível ao Malathion do que o peixe de água doce Oreochomis niloticus. Ao final do experimento todo o material utilizado foi cuidadosamente embalado e transportado para nossos laboratórios no Brasil.

Palavras-Chave: Peixe antártico - Anticolinesterásicos - Malathion - Notothenia neglecta.

\section{Introduction}

Organophosphate compounds are widely used as pesticides for the control of plagues in plants and animals. The wide and sometimes uncontrolled use of these agents have lead to toxicological problems to man and animals. Organophosphates have replaced the organochlorate derivatives as insecticides due to its shorter half-life, yielding by degradation water soluble products that are believed to be non toxic at all practical concentrations (WHO, 1986). The concept of "not pollutant" is referred to temperate climates and not assigned to the peculiar Antarctic conditions. Malathion is scarcely soluble in water and easily undergoes decomposition in alkaline medium, its half-life being about 32 hours at $\mathrm{pH} 7.4$ as referred by LARINI (1993). The $\mathrm{pH}$ of marine water at the Brazilian Antarctic Station was of 7.22 (Author's observation). This pesticide, despite its acute toxicity, is not considered an environmental pollutant and is secure enough to be sold commercially (National Academy of Sciences of National Research Council, 1959). As asserted by BASELT (1980), Malathion is one of the least toxic of the commercially available organophosphosphate insecticides, therefore one of the safest for domestic usage. However, several hundreds fatalities have been reported in man, usually after accidental or suicidal ingestion of large amounts of the chemical. The World Health Organization documents pesticides toxicity as a widespread global problem, most poisoning occuring in developing countries (BARDIN et al., 1994). Organophosphorous agents account for as much as $80 \%$ of pesticiderelated hospital admissions (TAYLOR, 1996) and acute toxicity only arises with suicidal attempts or deliberate poisonings (BARDIN, et 
al., 1994).

Organophosphate compounds cause long lasting inhibition of acetylcholinesterase (AChE) by sterification of hydroxyl residues of the enzyme on the sterasic sites, resulting an extremely stable complex (they are called "irreversible" anti-ChE). The resulting accumulation of non hydrolyzed molecules of acetylcholine at the cholinergic receptors causes a long lasting depolarisation of "end plates" at the neuromuscular synapses, stimulating this way and later blocking neuromuscular transmission ("nicotinic" action) as well as enhancing parasympathetic responses of target cholinergic structures ("muscarinic" action). The recovery of $\mathrm{AChE}$ activity depends upon the degree of spontaneous regeneration of the enzyme, or, in the case of very potent agents, upon the de novo synthesis of new enzyme molecules. Some of these agents (e.g. fluorinecontaining alkylorganophosphate anti-ChE compounds) induce a peculiar type of delayed neurotoxicity related to actions other than antiChE activity. Extensive compilations about organophosphate agents and their toxicity can be found in the publications of FREAR (1969), GAINES (1969), GALLO and LAWRYK (1991), TAYLOR (1996).

Toxicity of many pesticides to fishes was described by ALABASTER (1969). The toxicity of organophosphate anti-ChE agents to freshwater fishes was described by PICKERING et al., (1962), PICKERING and HENDERSON (1966), COPPAGE (1972), SYMONS (1973), BENKE and MURPHY (1974), POST and LEASURE (1974), DUANGSAWASDI and KLAVERKAMP (1979), LOPES et al., (1989), SILVA et al., (1993). Assays with Malathion were carried out by POST and LEASURE (1974), who determined its sublethal effect to salmonid species.

The Antarctic continent is the most untouched area of Earth. However, traces of pesticides were detected as early as 60's, in penguins (SLANDEN et al., 1966) and seals (GEORGE and FREAR, 1966). Since then, a number of pollutants have been detected, brought from foreign continents by marine and aerial currents (RISENBROUGH et al., 1968, 1990), not to discard the growing presence of man. Presence of PCBs (polichlorinated biphenyls) was detected in the atmosphere, sea water (TANABE et al., 1982, 1983; WEBER and MONTONE, 1990.; LARSSON et al., 1992) and also in rain water, krill and plants (MONTONE, 1995). McDONALD et al., (1992) reported the presence of polycyclic aromatic hydrocarbon metabolites in tissues of fishes from the Antarctic Peninsula and FOCARDI et al., (1992) detected traces of hexachlorobenzene (HCB), DDT and its derivatives DDE and DDD and about 20 polychlorinated biphenyls (PCBs) in tissues of seven species of Antarctic fishes from Ross Sea. The effects of acute exposure of an Antarctic fish Pagothenia borchgrevinki to water soluble fraction of diesel fuel oil was studied by DAVISON et al., (1992).

Presence of organophosphate compounds or their residues has not been detected in the Antarctic environment, as expected after their easy environmental inactivation. However, it must be considered that these agents could accidentally reach the Continent, carried out by occasional or permanent presence of man. In the case it happens, this arises the question of how could they affect fishes or other animals and in what extension. The sensitivity of the Antarctic fishes to acute or chronic exposition to organophosphate compounds has not been described. The aim of this research is to observe the sensivity of the Antarctic fish Notothenia neglecta to acute administration of the organophosphate anticholinesterase agent Malathion and to correlate the results with the degree of cholinesterase inhibition.

\section{Material and Methods}

Notothenia neglecta is endemic in the Admiralty Bay (King George Islands, South Shetlands), sharing these cold waters with many other species of the Antarctic widely distributed Nototheniidae (Pisces, Teleostei).

Specimens of Notothenia neglecta were caught in the Admiralty Bay, King George Island, South Shetlands, Antarctic, where the Antarctic Brazilian Station is settled. For the fishing it was used a special tri-mesh bottom net $60-100 \mathrm{~m}$ depth for $24-48 \mathrm{~h}$. The caught fishes were kept in aquarium with aerated marine water, at temperatures of $1.0-2.0^{\circ} \mathrm{C}$, for at least 15 days before the administration of Malathion. The water was daily monitored regarding to $\mathrm{pH}$ and salinity. To the animals was offered, weekly, sliced fresh fish flesh but the feeding was not predictable, as it is an usual behaviour of these fishes in "normal" aquarium conditions. For the experiments, the fishes were transferred to smaller experimental tanks, for individual observation. Eight adult animals were used.

Malathion was dissolved in corn oil, in the concentration of $30 \mathrm{mg} / \mathrm{ml}$ of active substance, and injected into the fish abdominal cavity. Two doses were used: $30 \mathrm{mg} / \mathrm{kg}$ (two fishes) and 15 $\mathrm{mg} / \mathrm{kg}$ (six fishes). The animals were observed all along the experiment regarding to: 1) - 
posture; 2) - reactivity to mechanical stimulus; 3 ) - occurrence of stimulation or depression; 4) opercular respiratory frequency and amplitude; 5) - body pigmentation; 6) - presence of faeces in the aquarium; 7) - mucus secretion. To the evaluation of behavior features, BEARENDS (1971) revision was considered.

Blood samples for determination of cholinesterase and total proteins were collected from the caudal vein of untreated animals (control) and of experimental animals at 12, 24, 36 hours and 10 days after the administration of Malathion. The assays were performed in individual samples. For the assay of cholinesterase and proteins, the whole blood was spun down for $30 \mathrm{~min}$ at $440 \mathrm{xg}$ and serum collected and used for this purpose. Cholinesterase was assayed according the method of DIETZ et. al. (1973). Protein determination was performed according to LOWRY et al. (1951).

At the end of the experiment the fishes were killed and liver, brain, heart, muscular mass and kidneys excised and immediately frozen at $10^{\circ} \mathrm{C}$, for later biochemical analysis.

Since the fate of the inactivation of Malathion is not known in Antarctic conditions, all the material used in the experiments or having any contact with the drug, was carefully set apart and packed back to our home laboratories in Brazil. The fishes, killed at the end of the experiments, were frozen and so carried back to our home laboratories.

\section{Results}

Behavioral and somatic responses. The fishes treated with either 15 or $30 \mathrm{mg} / \mathrm{kg}_{\mathrm{bw}}$ of Malathion kept normal stimulated swimming activity until about 5 hours after the injection. From about 6 hours to 5 days after the drug administration they were less reactive to stimulus or quite lethargic; two of them were catatonic, not reacting when put in unusual positions and indifferent to other noxious stimulus. Two fishes were quite stimulated within the first hours after the drug, swimming to and fro, but were later depressed. During the stimulated phase, the swimming was continuous, spontaneous and not stereotyped, using only the pectoral fins. During the depressive phase, most of them could swim vigorously when stimulated, in short burst speed pattern. Posture and balance were kept up all along the experiment (10 days). No muscular fasciculation was observed, indicating absence of cholinergic nicotinic stimulation at neuromuscular synapses. They usually refused food.

Somatic responses were quite clear: opercular respiratory movements were kept about the same amplitude all along the experiment but the respiratory rate decreased from $49( \pm 5.6)$ in controls to $27( \pm 5.8), 24$ hours after the drug and so remained for 5- 6 days, increasing later, but not returning to initial values up to the 10th day.

The body color gradually changed, starting from the 6th hour after the injection: at first, pale stains appeared along the ventral and lateral regions, then spread away, turning the whole body quite whitish, which persisted in most fishes up to the 10th day. In some of them, the head was quite darker than the rest of the body, giving the fish a two color unusual look that lasted all along the time of observation. The whitish color generally occurred during the calm or depressed phase.

After 6 to 10 hours of the administration of Malathion, the production of mucus was greatly increased and lasted for several days. It was somewhat parallel to the whitish color of the body. This time, it was observed also an increase in the amount of faeces in the water.

Two fishes to which Malathion was given in doses of $30 \mathrm{mg} / \mathrm{kg}_{\mathrm{bw}}$, died around 14 and 25 hours after the injection.

Serum cholinesterase. Specific activity of serum cholinesterase was considered as 100 per cent in not injected control fishes. After intra-abdominal injection of $15 \mathrm{mg} / \mathrm{kg}$ of Malathion, cholinesterase activity was inhibited in 52\% at $12 \mathrm{~h}$; in $59 \%$ at $24 \mathrm{~h}$ and at $70.4 \%$ at $36 \mathrm{~h}$. By the 10th day, it was observed a significant recovery of the enzyme activity, which had raised to levels of about $60 \%$ of the control values. In the two fishes to which $30 \mathrm{mg} / \mathrm{kg}$ of Malathion was administered, an inhibition of the cholinesterase enzymatic activity of $77 \%$ after 12 $\mathrm{h}$ was observed.

The specific activity was calculated as a ratio between the I.U. of the enzyme per L and values of seric protein calculated in $\mathrm{g} / \mathrm{L}$. Results are shown in Table 1 and Fig. 1.

\section{Discussion}

The preservation of Antarctic environment, avoiding the presence of any pollutant that could disturb the very sensitive balance of the ecosystem must be a major concern. However, the growing presence of the man in the area, despite the very strict rules controlling Antarctic occupation, always represents a risk to be considered. It is unlikely that organophosphorous 
residues can reach Antarctica, as waste brought from foreign continents by marine currents. They are not stable in aqueous media, undergoing hydrolysis; accidental leaching may occur (as far as to temperate zones is concerned) when they reach rivers and lakes in a rather large amount, exerting toxic effects on aquatic organisms before degradation is complete (WHO, 1986). It must be considered that the data about the inactivation of organophosphates either by water or by environment constituents may not fit the Antarctic conditions of very low temperatures, very dry air and different soil composition Although some pollutants have been detected in Antarctic Continent, in samples of water, animals and plants it is not established yet the real meaning of such agents to the aquatic or terrestrial life. The proposition of this research was to observe the sensitivity of the Antarctic fish Notothenia neglecta towards an organophosphate insecticide. Malathion was chosen because it is widely used, besides being not an environmental pollutant due to its rapid inactivation (see HAYES, 1989). Then, it can be supposed not to be aggressive to the Antarctic environment. On the other hand we decided to inject the drug directly into the fish abdominal cavity instead of dispersing it in the aquarium water, as it is a common practice in many published experiments, using commercial preparations, to avoid a large volume of liquid to be daily discarded. As the persistence of Malathion and other anti-AchE molecules are not known in Antarctic conditions, a special care was taken not to allow any environmental contact with the drug and all residues were brought back to our home laboratories.

Table 1. Blood serum cholinesterase (specific activity) in Notothenia neglecta, before (Control) and 12, $2436 \mathrm{~h}$ and 10 days after Malathion $(15 \mathrm{mg} / \mathrm{kg}$ ) administration by intraabdominal injection. Cholinesterase specific activity was calculated as a ratio between units (UI) of the enzyme $\mathrm{L}^{-1}$ and the concentration of protein in $\mathrm{g} \mathrm{L}^{-1}$.

\begin{tabular}{c|c|c|c|c|c}
\hline \multicolumn{7}{c}{ Serum cholinesterase (specific activity) } \\
\hline No. & Control & $12 \mathrm{~h}$ & $24 \mathrm{~h}$ & $36 \mathrm{~h}$ & 10 days \\
\hline 1 & 0.275 & - & 0.154 & 0.116 & - \\
2 & 0.270 & 0.117 & 0.106 & .0061 & 0.162 \\
3 & 0.270 & 0.121 & 0.102 & 0.061 & 0.158 \\
4 & 0.260 & - & - & 0.079 & 0.156 \\
5 & 0.270 & 0.157 & - & 0.085 & 0.156 \\
6 & 0.275 & 0.131 & 0.107 & 0.065 & 0.157 \\
7 & 0.255 & - & - & - & - \\
8 & 0.271 & - & - & - & - \\
\hline Mean/SD* & $0.268( \pm 0.007)$ & $0.131( \pm 0.017)$ & $0.117( \pm 0.024)$ & $0.078( \pm 0.021)$ & $0.158( \pm 0.002)$ \\
\hline
\end{tabular}

$* \mathrm{SD}=$ Standard Deviation

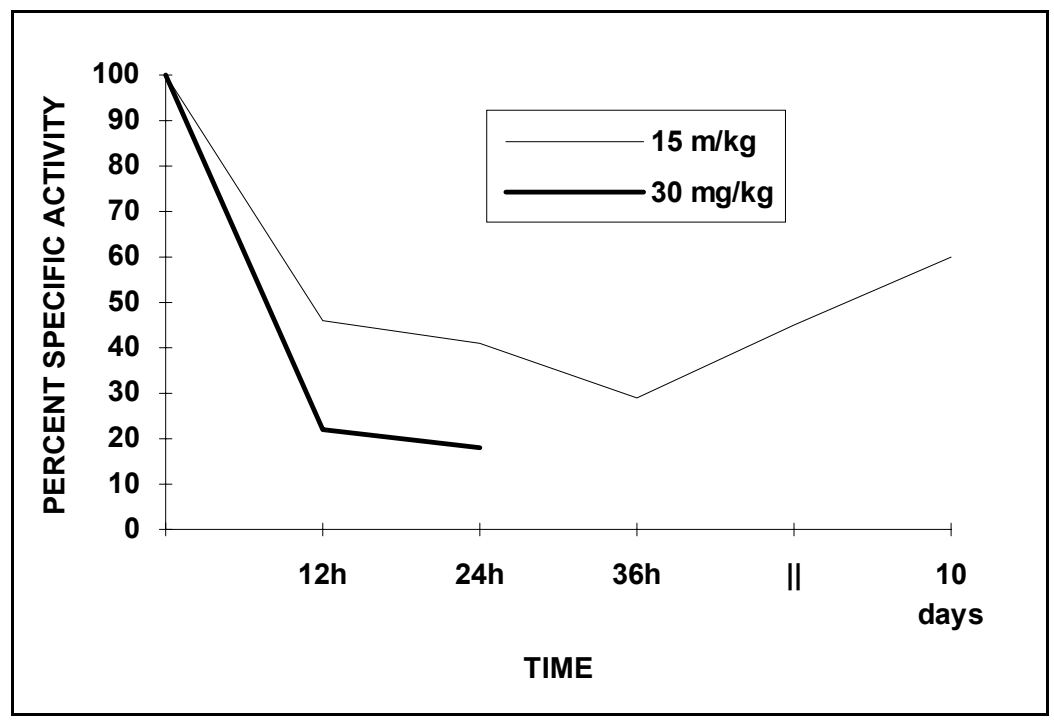

Fig. 1. Blood serum cholinesterase specific activity in the Antarctic fish Notothenia neglecta. Results of control (100\% specific activity) and of fishes injected with intramuscular Malathion, in doses of $15 \mathrm{mg} / \mathrm{kg}$ at 12, 24, 36 hours and 10 days after administration and $30 \mathrm{mg} / \mathrm{kg}$ after 12 hours. Specific activity was calculated as a ratio between units of enzyme per L/g protein per L (Uenz.L/g prot.L). 
The results obtained display the sensitivity of the Antarctic fish Notothenia neglecta to the toxic effects of Malathion, as compared to experiments carried out in fishes of temperate regions (PICKERING et al., 1962; PICKERING and HENDERSON, 1966; SYMONS, 1973; BENKE and MURPHY, 1974; POST and LEASURE, 1974; DUANGSAWASDI and KLAVENKAMP, 1979; LOPES et al., 1989; SILVA et al., 1993). The initial dose of $30 \mathrm{mg} / \mathrm{kg}$ used was based on those used by LOPES et al., (1989), who found that $40 \mathrm{mg} / \mathrm{L}$ of Malathion could induce severe intoxication in que freshwater fish Oreochromis niloticus. However, in the Antarctic fish, the dose of $30 \mathrm{mg} / \mathrm{kg}$ induced to death within 14 - 24 hours, although no clear signs of severe intoxication was observed within this interval. At these results, we decided by reducing the dose to a half, that is, $15 \mathrm{mg} / \mathrm{kg}$, intending a mild intoxication. These results indicate that Notothenia neglecta is more sensitive to the insecticide than the freshwater fish studied by those authors, despite different routes of administration were used.

Doses of $15 \mathrm{mg} / \mathrm{kg}$ induced somatic and behavioral responses that cannot be compared to those observed in freshwater fishes, using sub lethal doses of Methyl Parathion (SILVA et al., 1993) or Malathion (LOPES et al., 1989). Convulsions or muscular fasciculations, indicative of increased neuromuscular activity, central or cholinergic nicotinic in origin, were not observed. Body posture and equilibrium was not changed and most of the fishes kept the reflex of swimming at a gentle stimulus or in a burst way at a noxious stimulus and showing escaping reflex, indicative of a good physical condition. A central action of Malathion could be related to the hyperactivity observed in two fishes as well as the depression, observed in all of them along the experiment. However, except in the two fishes with a catatonic pattern, the animals showed a vigorous muscular response when manipulated, allowing no stereotyped behavior.

Regarding to respiration, it was not observed amplitude alteration of the opercular movements but a lowering in $50 \%$ of the respiratory rate at 24 hours, at the time when serum cholinesterase was inhibited in 59\%. However, respiration rate increased at the time the enzyme was inhibited up to $70.4 \%$. Then, it was not possible to establish a correlation between the two events. During the intoxication, the fishes refused food. Such anorexia could be related to the depressive state. However, such a refusing is also usual in control fishes, maybe due to some stress induced by the artificial conditions of an aquarium environment.
The whitish color observed 6.0-12.0 hours after the insecticide cannot be related to blood stream catecholamine due to stress, because the fish were usually calm and depressed. Cholinergic muscarinic responses were shown by higher presence of faeces, that was somewhat proportional to the degree of inhibition of cholinesterase. It is well known that organophosphate agents induce maximal inhibition of the enzyme in a short time, then slowly recovering its activity. In freshwater fish Callichthys callichthys (SILVA et al., 1993) cholinesterase inhibition by parathion was maximal at the 4th hour of administration and a $60 \%$ recovery occurred at the 24th day. In the $N$. neglecta the cholinesterase inhibition was not rapid in onset, as expected, but progressive up to the 36 hours after the drug. On the other hand, the enzyme activity was recovered in about $60 \%$ at the $10^{\text {th }}$ day.

These results lead to the supposition that in the Antarctic fish Notothenia neglecta Malathion is not metabolized at the same rate as in animals of temperate climates, problably as a result of their low body temperature and metabolism. It is important to point out that some insecticides such as Malathion, can be detoxified by hydrolysis of the carboxyl ester linkage by plasma carboxylesterases. The drug is known to lack a direct anticholinesterase activity, but it has to be metabolized to malaoxon, as a necessary prerequisite for its action as cholinesterase inhibitor (HAYES, 1989). The enzymes in liver that catalyses this reaction belongs to the group of NADPH-dependent mixed function oxidases of the microsomes (see LAUWERYS, 1994). In the Antarctic fish such biotransformation must be slower enough to explain the delayed inhibitory action on the enzyme. The somewhat rapid reactivation of the cholinesterase activity in a 10 days interval supposes a very active hepatic synthesis of new enzyme molecules in the Antarctic fish, not to discard an active hydrolytic regeneration of the phosphorylated sterasic site of acetilcholinesterase.

\section{Acknowledgements}

We are grateful to toxicologist Prof. Maria Elisa P. B. Siqueira for critical appreciation of the manuscripts and to Prof. Leimin Kou for her help in English revision.

\section{REFERENCES}

ALABASTER, J.S. Survival of fish in 164 herbicides, insecticides, fungicides, wetting agents and miscellaneous substances. Intern. Pest. Contr.11:29-35, 1969. 
BAERENDS, B.P. The ethological analysis of fish behaviour. In Hoar, W. S. \& Randall, D. J. Fish Physiology Vol. VI, Academic Press, New York. pp. 279-370, 1971.

BASELT, R.C. Biological Monitoring Methods for Industrial Chemicals. Biomedical Publ., Davis, California, pp. 172-173, 1980.

BARDIN, P.G.; VAN EEDEN, S.F.; MOOLMAN, J.A.; FODEN, A. P.; JOUBERT, J.R. Organophosphate and carbamate poisoning. Arch. Intern. Med. 154:1433-1441, 1994.

BENKE, G.M.; MURPHY, S.D. (1974) Anticholinesterase action of methyl parathion, parathion and azinphosmethyl in mice and fish: onset and recovery of inhibition. Bull. Envir. Contam. Toxic. 12:117-122, 1974.

COPPAGE, D.L. Organophosphate pesticides: specific of brain AchE inhibition related to death in sheephead minnows. Trans. Am. Fish. Soc. 101:534, 1972.

DAVISON, W.; FRANKLIN, C.E.; MACKENZIE, J.C.;DOUGAN, M.C.R. The effects of acute exposure to the water soluble fraction of diesel fuel oil on survival and metabolic rate of an Antarctic fish Pagothenia borchgrevinki. Comp. Biochem. Physiol. C. 102:185-188, 1992.

DIETZ, A.A.; RUBINSTEIN, H.; LUBRANO, T. Colorimetric determination of serum cholinesterase and its genetic variant propionylthiocholine-dithiobi itrobenzoic acid) procedure. Clin. Chem. 19:1309, 1973.

DUANGSAWASDI, M.; KLAVERKAMP, J.F. Acephate of fenitrothion toxicity in rainbow trout: effect of temperature stress and investigations on the sites of action. In: Aquatic Toxicology (Edited by Marking L.L. and Kimerle R.A.), 35. Am. Soc. for Testing and Materials, Philadelphia,1979.

FOCARDI, S.; LARI, L.; MARSILI, L. PCB congeners, DDTs and Hexachlororobenzene in Antarctic fish from Terra Nova Bay (Ross Sea). Antarctic Science 4:151-154, 1992.

FREAR, D.E.H. Pesticide Index, 4th ed. College Science Publs., State College, Pa, 1969.

GAINES, T.B. Acute toxicity of pesticides. Toxicol. Appl. Pharmacol. 14:515 - 534, 1969.

GALLO, M.A.; LAWRYK, N.J. Organic phosphorous pesticides. In: Handbook of pesticide toxicology, (Edited by Hayes, W. J. and Laws, E. R. Jr.) Academic Press, San Diego, 2:917-1123, 1991

GEORGE, J.L.; FREAR, D.E.H. Pesticides in Antarctic. J. Appl. Ecol. 3:155-157, 1966.

HAYES A.W. Principles and Methods in Toxicology. Raven Press, New York, pp. 140-142, 1989.

LARINI, L. Toxicologia, Ed. Manole, S.Paulo, 141 pp, 1993.

LARSSON, P.; JARNMARK, C.; SODERGREN, A. PCBs and Chlorinated pesticides in the atmosphere and aquatic organisms of Ross Island, Antarctica. Mar. Pollut. Bull. 25:281-287, 1992.

LAUWERYS, R.R. Industrial Chemical Exposure: Guidelines for Biological monitoring. Biomedical Publs., Davis, California, pp. 416421, 1994.
LOPES, L.R.; SANTOS, J.P.; DELL'AQUA, C.R.; DELCARRATORE; HOSHINO, K. Recovery of Malathion-intoxicated freshwater fish by exposure to hypertonic environment. Braz. J. Med. Biol. Res. 22:269-273, 1989.

LOWRY, O.H.; ROSENBROUGH, H.J.; FARR, A.L.; RANDALL, J.R. Protein measurement with the Folin phenol reagent. J. Biol. Chem. 193:263-276, 1951.

MCDONALD, D.S.J.; KENNICUTT, M.C. II; BROOKS, J.M. Evidence of polyciclic aromatic hydrocarbon (PAH) exposure in fish from the Antarctic Peninsula. Marine Pollution Bull. 25:313317, 1992.

MONTONE, R.C. Determinação de Bifenilos Policlorados (PCBs) no ambiente Antártico. Thesis, Instituto de Química, Universidade de S. Paulo, 98 pp, 1995.

NATIONAL Academy of Sciences of National Research Council. Insecticides, vol. III, Saunders Co., London, pp. 451-463, 1959.

PICKERING, Q.H.; HENDERSON, C. The acute toxicity of some pesticides to fish. Ohio J. Sci. 66:508-513, 1966.

PICKERING, Q.H.; HENDERSON, C.; LENKE, A.E. The toxicity of organic phosphorus insecticides to different species of warmwater fishes. Trans. Am. Fish Soc. 91:175-182, 1962.

POST, G.; LEASURE, R.A. Sublethal effect of Malathion to three salmonid species. Bull. Envir. Contam. Toxic. 12:312- 319, 1974.

RISENBROUGH, R.W.; REICHE, P.; PEAKALL, D.B.; HERMAN, S.G.; KIRVEN, N.M. Polychlorinated biphenyls in the global ecosystem. Nature, 264:738$739,1968$.

RISENBROUGH, R.W.; DE LAPPE, B.W.; YOUNGHANS-HAUG, C. PCB and PCT contamination in Winter Quarters Bay, Antarctica. Mar. Poll. Bull. 21: 523-529, 1990.

SILVA, H.C.; MEDINA, H.S.G.; FANTA, E.; BACILA, M. Sublethal effects of the organophosphate Folidol 600 (Methyl Parathion) on Callichthys callichthys (Pisces: teleostei) - Comp. Biochem. Physiol. 105: 197201, 1993.

SLANDEN, W.J.L.; MENZIE, C.M.; REICHEL, W.L. DDT residues in Adelie penguins and a crabeater seal from Antarctica. Nature, 210:670-673, 1966.

SYMONS, P.E.K. Behavior of young Atlantic salmon (Salmo salar) exposed to or force-fed fenitrothion, an organophosphate insecticide. J. Fish. Board. Can. 30:651-655, 1973.

TANABE, S.; HIKADA, H.; TATSUKAWA, R. PCBs and chlorinated hydrocarbons pesticides in Antarctic atmosphere and hydrosphere. Chemosphere, 12:277288,1983

TANABE, S.; TATSUKAWA, R.; KAWANO, M.; HIKADA, H. Global distribution and atmospheric transport of chlorinated hydrocarbons: $\mathrm{HCH}(\mathrm{BHC})$ isomers and DDT compounds in the Western Pacific, Eastern Indian and Antarctic Oceans. J. Oceanogr. Soc. Japan., 38:137-148, 1982.

TAYLOR, P. Anticholinesterase agents. In Goodman \& Gilman's The Pharmacological Basis of Therapeutics.(Editors Hardman J. G., Limbird, L. E., Molinoff, P. B., Ruddon, R.W. and Gilman, A. G.) 9th ed., McGraw-Hill, pp.161-176, 1996. 
Sensitivity of Antarctic fish to the Anticholinesterase Agent Malathion

WEBER, R.R.; MONTONE, R.C. Distribution of organochlorines in the atmosphere of the South Atlantic and Antarctic Oceans: In: Kurtz, D. A. ed. Long transport of pesticides, Lewis Publishers, pp. 185-197, 1990
WHO (WORLD HEALTH ORGANIZATION) Organophosphorous Insecticides: a general introduction. Environmental Health ACriteria 63, Geneve, 1986. 